\title{
PENAMAAN BUSANA WANITA PADA MEDIA ONLINE SHOP
}

\author{
Naming Woman's Clothing In The Online Media Shop \\ Ely Irmawatia,", M Rais Almajid b,*, Ferdian Achsani ${ }^{\text {c,* }}$ \\ a,b,c Institut Agama Islam Negeri Surakarta \\ Jalan Pandawa, Pucangan, Kartasura, Sukoharjo \\ Pos-el: dwikurniawan219@gmail.com
}

(Naskah Diterima Tanggal 12 September 2019-Direvisi Tanggal 4 Maret 2020_Disetujui Tanggal 23 Maret 2020)

\begin{abstract}
This study aims to determine the lexical meaning of the types of women's clothing and naming factors in the clothing itself. Because fashion is one of the things that are in great demand by women. The method used is a descriptive method by analyzing the meaning and naming factors of the types of lexical names in a market that are traded to consumers. The data collection technique used is to write and photograph. The data analysis is carried out in three stages, namely searching for data, managing data, and presenting data. The results of the study showed that the naming of the dresses was caused by various factors such as identity, similarity of features, abbreviations. The naming is classified in the category of naming 8 plants, 7 animals, 12 names of people representing, and 12 nouns. Naming clothes with names such as names of people, animals, plants and names of objects has the aim to give meaning to clothing products that are made according to the nature or character of the product name
\end{abstract}

Keywords: fashion, naming, semantic

\section{PENDAHULUAN}

Fashion di Indonesia saat ini berkembang sangat pesat dengan mengikuti arus modernisasi. Dengan adanya fashion yang semakin beragam, masyarakat menjadi lebih selektif untuk memilih sesuai dengan gaya yang diinginkan. Fashion sendiri merupakan model gaya berbusana yang dipakai oleh setiap orang. Sebagaimana yang kita ketahui bahwa Busana merupakan salah satu kebutuhan primer manusia di samping pangan dan papan. Pada awalnya busana hanya digunakan sebagai pelindung tubuh manusia dari sengatan terik matahari maupun dinginnya udara. Namun seiring dengan perkembangan dan peradaban budaya manusia, berbusana juga bertujuan untuk menambah keindahan serta dapat menutupi kekurangan dalam menjaga penampilan, dengan demikian diperlukan busana dan pelengkapnya seperti hiasan pada busana. Hal ini sesuai pendapat Hapsari and Mohammad (2018) bahwa fungsi fashion sudah bergeser menjadi tuntutan terpenuhinya gaya hidup (lifestyle) masyarakat. Diperjelas oleh Umboh, Lisbeth, and Reitty ( 2018) bahwa fashion juga berfungsi sebagai refleksi dari status sosial dan ekonomi yaitu fungsi yang menjelaskan tentang popularitas

Menurut Poerwadarminta (2005) busana adalah pakaian atau sesuatu yang indah-indah serta terdpat perhiasan yang melengkapinya. Semakin berkembangnya zaman, busana wanita muncul banyak tren untuk memuaskan konsumen serta sesuai dengan model yang sudah disesuaikan. Busana dapat dibedakan menjadi dua pengertian yaitu secara sempit adalah busana sebagai pakaian sedangkan dalam arti luas busana diartikan sebagai pakaian dan pelengkapnya (Lutfiati, 2017).

Busana bagi perempuan dijadikan sebagai bahan untuk mempercantik diri. Dalam ajaran agama, perempuan adalah hiasan dan hiasan yang paling berharga 
adalah perempuan solehah. Perempuan solehah merupakan harga mutlak bagi idola kaum adam. Namun juga tidak dapat dihindarkan bahwa penampilan juga menjadi perhiasan bagi perempuan. bahkan peribahasa jawa mengatakan bahwa ajining raga soko busono (jati diri badan atau tubuh dari busana), menandakan bahwa busana juga berperan penting dalam membentuk kepribadian dan harga diri terutama bagi seorang perempuan.

Penjualan busana perempuan di era modern ini semakin meningkat. Pemanfaatan internet digunakan sebagai salah satu alat atau sarana untuk menawarnakn produk busana. fenomena jual beli online telah tumbuh dan menjamur ditengah-tengah kehidupan sehari-hari (Fitria, 2017). Bahkan fenomena jual beli online telah mengundang MUI untuk memberikan pernyataan terkait halal atau haram. Masyarakat lebih efisien dalam berbelanja melalui media online, karena mereka tidak harus keluar rumah dan panaspanasan mencari barang, belum lagi jika barang tersebut tidak ditemukan di toko yang telah dituju. Adanya online shop ini mempermudah masyarakat di manapun dan kapanpun dalam mancari barang.

Tidak perlu mengunjungi online shop, masyarakat bahkan dapat memanfaatkan status wa untuk menawarkan barang dagangangan. Hal ini disampaikan oleh (Rifauddin, 2016), jika remaja laki-laki menggunakan internet untuk membuka web dan bermain game online, maka remaja perempuan menggunakan internet untuk membuka jejaring sosial, chatting, dan berbelanja lewat online shop. Dari jejaring sosial tersebut semakin dijumpai jenis-jenis busana yang beraneka ragam dengan model yang mengikuti tren masa kini.

Beragamnya model busana-busana bagi kalangan masyarakat, semakin beragam banyak pula nama-nama unik dalam penamaan busana. Penamaan namanama busana tersebut dilakukan untuk memudahakan para konsumen dalam memilih model yang diinginkan serta menjadi daya tarik tersendiri bagi konsumen. Penaaman tersebut salah satunya dapat dilihat sebagai berikut.

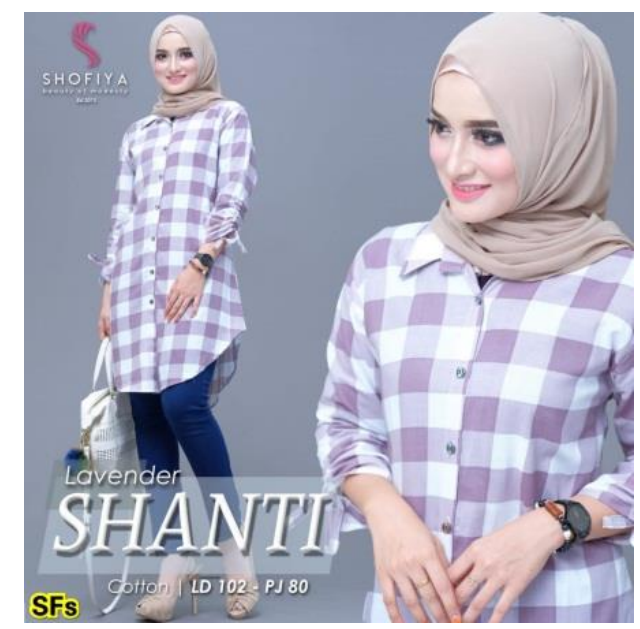

Gambar 1. Busana perempuan

Gambar di atas merupakan salah satu model busana perempuan dengan penamaan bunga lavender. Dalam gamabr tersebut terlihat jelas bahwa perempuan begitu cantik dengan menggenakan busana tesebut. Hal yang menarik di sini adalah penamaan bunga Lavender pada nama busana tersebut. pemanfaatan bunga lavender sebagai nama busana tersebut memiliki makna terhadap busana tersebut. Bunga Lavender sebagaimana yang kita ketahui merupakan bunga berwarna ungu, adapula yang putih yang mekar di negeri kincir angin ini, memiliki daya keindahan yang menarik hati dan memiliki aroma yang khas. Bahkan bunga ini digunakan sebagai salah satu produk obat nyamuk karena aroma khasnya ini. penggunaan nama bung sebagai nama busana .... bunga ini sebagai nama busana memiliki makna bahwa pemakai busana tersebut akan memiliki keelokan yang terpancar layaknya bunga lavender. Hal ini dapat dilihat dari busana tersebut yang memiliki warna ungu yang mencolok dan indah. Penamaan yang demikian dapat dikaji melalui kajian semantik.

Semantik yang merupakan cabang ilmu linguistik yang mempelajari tentang seluk-beluk makna selalu berusaha untuk menguraikan nama-nama dibalik sesuatu, 
salah satunya pada busana. Di dalam kajian semantik, terdapat beberapa jenis makna seperti makna konseptual, makna kontekstual, makna gramatikal, makna leksikal, makna konotasi, makna denotasi, dan lain sebagainya.

Makna leksikal adalah makna kata atau leksem sebagai lambang benda, peristiwa, objek, dan lain-lain.Makna ini dimiliki unsur bahasa lepas dari penggunaan atau konteksnya.Misalnya, kata tikus bermakna "binatang pengerat yang bisa menyebabkan penyakit tifus."Makna leksikal juga bisa diartikan sebagai makna yang terdapat di dalam kamus, yaitu makna yang mewakili sebuah kata.

Penelitian ini bertujuan untuk mendeskripsikan makna leksikal yang terdapat pada nama-nama busana wanita. Tujuan lain dalam penelitian tersebut adalah untuk menjabarkan makna dibalik penama-aan fashion busana tersebut.

Makna leksikal adalah makna satuansatuan kebahasaan yang dapat diidentifikasikan tanpa satuan itu bergabung dengan satuan lingual yang lain (Wijana, 2015). Misalnya, kata ayah memiliki makna 'orang tua laki-laki', ibu 'orang tua perempuan', tidur 'merebahkan tubuh sambil menutup mata', lantai 'bagian dasar rumah yang terbuat dari semen atau ubin'. Ketiga kata ini memiliki makna leksikal.Makna-makna itu mengacu pada sesuatu atau konsep di luar bahasa.Akan tetapi, untuk membuat atau membentuk kalimat, satuan-satuan yang memiliki makna leksikal itu harus dikombinasikan dengan berbagai aturan atau kaidah gramatikal.

Makna leksikal yakni makna yang dimiliki atau yang terdapat pada leksem meski tidak ada konteks apapun, oleh karenanya makna leksikal merupakan makna sebenarnya. Hal ini seperti yang diutarakan oleh Kearns (2000: 3) bahwa makna leksikal sebagai makna dari kata itu sendiri, sedangkan bidang yang meneliti semantik leksikal menurut asas-asanya dinamai "leksikologi”. Wijana (2015) menambahkan makna yang dimiliki atau ada pada leksem meskipun tidak ada konteks apapun. Misalnya makna leksem kuda memiliki makna leksikal sejenis binatang berkaki empat yang dapat dikendarai.

Makna leksikal merupakan arti kata sebagai satuan yang bebas.Umumnya, dianggap sejajar dengan arti denotatif atau artinya yang berdasarkan kamus (Rahmawati, 2018). Makna leksikal adalah makna kata atau leksem sebagai lambang benda, peristiwa, objek, dan lainlain.Makna ini dimiliki unsur bahasa lepas dari penggunaan atau konteksnya.Misalnya, kata sapi bermakna "binatang berkaki empat yang dapat dikonsumsi". Di dalam penamaan model busana dilakukan dengan menggunakan lambang leksikal yang dilatarbelakangi oleh sebab-sebab atau peristiwa. Salah satunya jenis nama-nama busana juga terbentuk karena adanya penemu atau pembuat yang menamakan temuanya. Dalam (Suwandi, 2008) mengatakan bahwa penamaan dalam benda ataupun hal yang lainya dilatarbelakangi oleh penemu, tempat asal, bahan, kesamaan ciri, dan singkatan.

Dalam penelitian ini ditemukan beberapa kosakata yang digunakan untuk penamaaan busana wanita saat ini. Tetapi, kosakata yang ditemukan, kebanyakan menggunakan bahasa Inggris. Kata yang digunakan terdapat kategori nomina, adjektiva, dan terdapat juga nama dari sebuah hewan, nama daerah, nama orang, dan tumbuhan.

Penelitian seperti penamaan dalam benda juga pernah dilakukan oleh (Ulfiana, 2016) dalam penelitian yang berjudul "Satuan Lingual Penanda Aroma pada parfum"yang di dalamnya terdapat penandaan lingua pada jenis-jenis parfum. Perbedaan ini dilakukan untuk membedakan aroma pada parfum.Dari hasil presentase analisis satuan kebahasaan penanda aroma pada parfum, dapat disimpulkan bahwa bentuk frasa nomina mendapatkan jumlah paling tinggi dengan 
skor persentase sebesar 59,2\%, sedangkan bentuk klausa mendapatkan jumlah paling rendah dengan skor persentase $0,58 \%$. Dari hasil perhitungan di atas menunjukkan bahwa bentuk frasa nominal mendominasi dalam menandai aroma pada parfum.Hal tersebut disebabkan oleh bentuk nomina lebih jelas (asosiasi langsung) dalam menandai aroma pada parfum.

Dalam penelitian yang dilakukan oleh Inderasari dan Wahyu (2019) dalam artikel yang berjudul "Satuan Eksperesi Penamaan dan Persamaan Warna dalam Produk Lisptik" menunjukan hasil bahwa adanya wujud satuan ekspresi warna pada produk lipstik dan satuan ekspresi persamaan lipstik. Penaamaan pada lipstick ini bertujuan untuk menarik minat konumsem untuk membeli produk yang ditawarkan.

Penelitian Rohardiyanto

(2019)

menunjukkan bahwa hasil penamaan pada diri seorang memiliki harapan-harapan yang telah disesuaikan dengan makna nama aslinya. Penamaan mahasiswa di IAIN Surakarta dibentuk berlandaskan dengan kombinasi nama dengan orang tua, dibentuk dari ayah atau ibu, dan dibentuk dari akronim khusus.

Beberapa kajian di atas menunjukkan masih terbatasnya penelitian terhadap penamaan busana. Hal ini menjadi salah satu sebab untuk meneliti penamaan pada busana wanita. Tujuan yang dilakukan adalah untuk mengetahui sebab penamaan dan makna lekiskal dalam jenis model busana yang dilakukan oleh produsen atau penjual. Perbedaan dengan kedua penelitian tersebut terdapat pada objek kajian yang diteliti yaitu antara penamaan produk liptik dan nama mahasiswa dengan nama-nama busana wanita.

\section{METODE}

Metode yang digunakan dalam penelitian ini adalah mengunakan metode observasi dan metode deksripsi. Metode obeservasi merupakan langkah awal dalam mencari atau menemukan data dengan melihat langsung data yang ada. Teknik dalam pengambilan datapun dilakukan dengan tiga cara seperti, proses mencari data, mengelola data, dan menyajikan data (Sugiyono 2014). Teknik pengumpulan data ini, peneliti melakukan dengan cara mengamati, menulis, dan memfoto objek kajian. Mencari data ini dilakukan untuk mendapatkan konsep kajian yang digunakan. Teknik mengelola data merupakan teknik lanjutan yang digunakan peneliti setalah mendapatkan data-data yang diperlukan. Data tersebut lalu dikelola untuk diklasifikasikan sesuai dengan jenis konsep yang sudah ditentukan peneliti.

Setelah dilakukan teknik pengklasifikasian dilakukan analisis, mengambarkan, dan memaparkan sebuah objek yang dikaji secara jelas dan terperinci. Peneltian ini difokuskan untuk membahas dan menganalisis tentang namanama busana wanita yang ada di sosial media khususnya instagram. Kemudian nama-nama busana yang sudah dikumpulkan tersebut. Lalu diketegorikan dan dianalisis sesuai dengan kategorinya. Nama-nama busana wanita tersebut lalu diklasifikasikan sesuai dengan kategori seperti nama orang, tumbuhan, hewan, buah, dan nama daerah. Untuk memudahkan dan mempercepat penulis dalam mencari sampel dalam penelitian ini adalah dengan cara mencari olshop busana wanita di instagram, kemudian memilih nama-nama busana wanita yang sering digunakan

\section{HASIL DAN PEMBAHASAN}

Dari hasil penelitian dapat ditemukan beberapa data mengenai nama-nama yang digunakan dalam busana wanita Data tersebut seperti Lucie dress, Olivia Dress, Flore Dress Mint, Rosie Dress, Zelia Kaftan, Aliya Dress, Kanza Kaftan Pistachio, Maple Embroidery Dress, Lilou Dress, Sana Dress, Elise Tunic, Pickle Mandarin Shirt, Linen Buttoned Shirt, Lily Paige Outwear, dan lain-lain. Semua data tersebut diklasifikasikan sesuai dengan 
kategorinya. Nama-nama busana tersebut diklasifikasikan seperti nama orang, nama tumbuhan, nama hewan, dan nomina. Nama-nama tersebut dianalisis dan diklasifikasi sebagai berikut.

\section{Nama Orang}

Dalam penelitian ini ditemukan nama busana wanita yang menggunakan nama orang. Rahmawati mengatakan (Bakti, 2018) bahwa nama merupakan atribut pribadi yang memiliki fungsi sebagai sarana untuk mengidentifikasi seseorang, dan selalu digunakan untuk beragam kepentingan, sejak ia lahir hingga nama tertulis di batu nisan. Dalam banyak konteks, nama dibubuhkan pada berkasberkas administrasi, nama juga muncul saat seseorang berhasil menelurkan sebuah mahakarya. Data tersebut seperti berikut.

Tabel 1 Nama Orang Pada Merek Busana

\begin{tabular}{lll}
\hline No & Jenis & Makna \\
\hline 1 & Olivia Dress & Olivia Gaun \\
\hline 2 & Rosie Dress & Rosie Gaun \\
\hline 3 & Elise Tunic & Elisa Jubah \\
\hline 4 & Aliya Dress & Aliya Gaun \\
\hline 5 & Zelia Dress & Zelia Gaun \\
\hline 6 & Sofia Outerwear & Sofia Baju \\
\hline 7 & Syifa Dress & Syifa Gaun \\
\hline 9 & Paula Tunic & Paula jubah \\
\hline 10 & Paula Tunic & Paula Jubah \\
\hline 11 & Malika Tunic & MalikaJubah \\
\hline 12 & Aisya Tunic & Adina Jubah \\
\hline
\end{tabular}

Data di atas menunjukkan namanama busana wanita menggunakan nama orang sebagai penanda busana tersebut. Nama tersebut sering digunakan dalam nama busana wanita yang setiap nama memiliki model fashion yang berbeda. Nama-nama tersebut dipilih berdasarkan setiap nama tersebut memiliki makna yang mewakili gaya fashion yang dipilih. Pada setiap nama memiliki model seperti baju atasan dan outer. Nama yang digunakan mempunyai kategori nomina atau nama benda. benda atau sejenis yang ditemukan biasanya lebih cenderung diberi nama oleh sang penemunya sendiri atau memang diambil dari nama orang lain sebab nama orang lain dirasa dapat mewakili sifat dari baju tersebut. Tetapi juga tidak dapat dipungkiri bahwa pemberian nama orang sebagai nama busana dilakukan berdasarkan nama penemunya atau pembuatnya (Suwandi, 2008). Nama-nama tersebut biasa dikenal dengan istilah Apellativa.

Misalnya pada nama Aliya Dress, kata tersebut mempunyai leksem Aliya dan leksem dress. Leksem Aliya merupakan nama seseorang dan merupakan kategori nomina. Sedangkan leksem dress, jika diartikan dalam bahasa Indonesia merupakan pakaian atau gaun. Leksem tersebut merupakan kategori nomina. Dalam bahasa Arab nama Aliya memiliki arti seorang bangsawan. Hal ini berpengaruh terhadap nama yang terdapat pada busana tersebut. Penamaan busana wanita dengan nama demikian memiliki maksud bahwa perempuan yang menggunakannya akan berpenampilan layaknya seorang putri bangsawan. Pemberi nama memberikan nama tersebut dengan tujuan karena nama orang tersebut dapat mewakili busana yang diciptakannya.

Pada nama busana Elise Tunic, kata tersebut mempunyai leksem Elise dan tunic. Leksem Elise biasanya digunakan nama untuk seseorang dan merupakan kategori nomina. Sedangkan leksem tunic, jika diartikan dalam bahasa Indonesia merupakan jubah. Leksem tersebut merupakan kategori nomina. Elise dalam bahasa Arab memiliki karakter yang penuh dengan gairah. Penamaan busana dengan nama Elise ini bertujuan untuk memberikan penampilan yang menggairahkan kepada si pemakai. Perempuan yang mempergunakan pakaian tersebut dipandang sebagai perempuan yang penuh dengan gairah sesuai dengan desain pakaian tersebut.

Pada nama Malika Tunic, kata tersebut mempunyai leksem Malika dan leksem tunic. Leksem Malika biasanya digunakan untuk nama seseorang dan 
merupakan kategori nomina. Sedangkan leksem tunic, jika diartikan dalam bahasa Indonesia merupakan jubah. Leksem tersebut merupakan kategori nomina. Kata Malika dalam bahasa Arab memiliki makna ratu. Penggunaan nama Malika pada busana perempuan ini bermaksud bahwa perempuan yang menggunakannya akan tampil seperti layaknya seolah ratu.

\section{Nama Tumbuhan}

Dalam penelitian ini ditemukan nama busana wanita yang menggunakan nama jenis tumbuhan. Data tersebut seperti berikut.

Tabel 2 Nama Tumbuhan pada fashion perempuan

\begin{tabular}{lll}
\hline \multicolumn{2}{c}{ perempuan } & Terjemah \\
\hline 1 & Flore Dress Mint & $\begin{array}{l}\text { Gaun } \\
\text { Tumbuhan } \\
\text { Mint }\end{array}$ \\
\hline 2 & Flore Dress & $\begin{array}{l}\text { Gaun } \\
\text { Tumbuhan }\end{array}$ \\
\hline 3 & Maple Embroidery & $\begin{array}{l}\text { Gaun Border } \\
\text { Maple }\end{array}$ \\
\hline 4 & Rress & Gaun Mawar \\
\hline 5 & Floral Fress & Kemeja Bunga \\
& Shirt & Mengalir \\
\hline 6 & Apple Set & Apel Set \\
\hline 7 & Melati Set & Melati Set \\
\hline 8 & Gamis Palm & Gamis Palem \\
\hline 9 & Olive Dress & Gaun Zaitun \\
\hline
\end{tabular}

Data di atas menunjukkan nama-nama busana wanita menggunakan nama tumbuhan sebagai penanda busana tersebut. Nama tersebut sering digunakan dalam nama busana wanita yang setiap nama memiliki model atau gaya baju yang berbeda. Pada setiap nama memiliki model seperti baju atasan dan outer. Nama yang digunakan mempunyai kategori nomina atau nama benda. Penggunaan nama jenis tumbuhan biasanya lebih sering dinamakan dengan dilatarbelakangi oleh motif yang khas dengan tumbuhan yang dimaksud. Seperti Apple Set yang tentu motifnya lebih cenderung banyak ditemukan motif khas buah appel sebagai corak busana tersebut.

Misalnya pada nama Olive Basic, kata tersebut mempunyai leksem olive dan leksem basic. Leksem Olive, jika diartikan dalam bahasa Indonesia merupakan tumbuhan buah zaitun. Buah zaitun merupakan kategori nomina atau kata benda. Sedangkan leksem basic, jika diartikan dalam bahasa Indonesia merupakan dasar atau utama. Leksem tersebut mempunyai kategori nomina atau kata benda. Tumbuhan zaitun merupakan salah satu tumbuhan yang paling banyak manfaatnya. Selain dapat dioleh menjadi minyak yang memiliki banyak manfaat bagi tubuh manusia, tangki atau dahan pohon tersebut juga dapat digunakan sebagai lambing perdamaian. Masyarakat Yunani memandang tumbuhan zaitun ini sebagai sumber kemakmuran. Penamaan busana dengan nama demikian bertujuan untuk memberikan makna bahwa perempuan yang menggunakannya akan berkesan sebagai perempuan yang makmur.

Pada nama Flore Dress, kata tersebut mempunyai leksem flore dan leksem dress. Leksem flore, jika diartikan dalam bahasa Indonesia merupakan bunga kecil. Bunga kecil merupakan kategori nomina atau kata benda. Sedangkan leksem dress, jika diartikan dalam bahasa Indonesia merupakan pakaian atau gaun. Leksem tersebut mempunyai kategori nomina atau kata benda. Bunga merupakan salah satu tanaman yang dapat digunakan untuk hiasan rumah ataupun ruangan. Terdapat Bermacam-macam bunga dengan aroma dan penampilan indah yang menarik masyarakat untuk menggunakannya sebagai bahan dekorasi. Penamaan nama bunga pada busana perempuan juga memiliki makna untuk memberikan keindahan bagi si pemakai. Dengan demikian pemakaian busana ini akan memberikan penampilan yang menarik dan indah.

Pada nama melati set kata tersebut mempunyai leksem melati, leksem dan leksem set. Leksem melati, jika diartikan 
dalam bahasa Indonesia merupakan sejenis bunga melati. bunga melati termasuk dalam kategori nomina atau kata benda. Leksem set, jika diartikan dalam bahasa Indonesia merupakan kain setel. Leksem tersebut mempunyai kategori nomina atau kata benda. Melati merupakan salah satu bunga yang memiliki julukan Puspa bangsa i. Warna nya yang putih dan baunya yang wangi, melati dapat dipandang sebagai bunga yang melambangkan kesucian. Tak hanya itu bunga melati juga melambangkan keanggunan yang sederhana, dan ketulusan. Penamaan busana wanita dengan tumbuhan melati memiliki maksud bahwa pengguna pakaian tersebut memiliki kesucian yang dapat dilihat dari busana.

\section{Nama Binatang}

Dalam penelitian ini ditemukan nama busana wanita yang menggunakan nama binatang. Data tersebut seperti berikut.

Tabel 3 Nama Binatang Pada Merek Pakaian

\begin{tabular}{|c|c|c|}
\hline No & Nama & Terjemah \\
\hline \multirow[t]{3}{*}{1} & Flamingo Flowing & Kemeja \\
\hline & Shirt & Flamingo \\
\hline & & Mengalir \\
\hline \multirow[t]{2}{*}{2} & Flowing & Kemeja Angsa \\
\hline & Shirt & Mengalir \\
\hline \multirow[t]{2}{*}{3} & Houndstooth & Pakaian Luar \\
\hline & Outerwear & Houndstooth \\
\hline 4 & Rusa Zola & Rusa Zola \\
\hline 5 & Dinanti Bear & Dinanti Beruang \\
\hline \multirow[t]{2}{*}{6} & Blouse $\quad$ Capung & Blus $\quad$ Capung \\
\hline & Kiminom & Kimonim \\
\hline \multirow[t]{2}{*}{7} & Tunik $\quad$ Sarimbit & Tunik Sarimbit \\
\hline & Merak & Merak \\
\hline
\end{tabular}

Data di atas menunjukkan nama-nama busana wanita menggunakan nama binatang sebagai penanda busana tersebut. Nama tersebut sering digunakan dalam nama busana wanita yang setiap nama memiliki model atau gaya baju yang berbeda. Pada setiap nama memiliki model seperti baju atasan dan outer. Nama yang digunakan mempunyai kategori nomina atau nama benda. Seperti halnya pada model tumbuhan. Model hewan dalam penamanaaya juga lebih banyak dilatarang belakangi oleh motif yang hiasan yang seperti hewan atau warna yang terlukis di busana cenderung mirip dengan warna hewan. Burung adalah salah satu motif yang sering digunakan produsen untuk mempertarik para konsumen.

Misalnya pada nama Dinanti Bear, kata tersebut mempunyai leksem Dinanti, dan leksem Bear. Leksem dinanti, merupakan nama orang yang digambarkan memiliki karakter berwibawa. Leksem Bear, jika diartikan dalam bahasa Indonesia yaitu beruang. Beruang merupakan binatang besar dan memiliki bulu yang lebat. Hewan yang suka tidur di musim dingin ini menjadi idola para perempuan karena tampangnya yang lucu dan menggemaskan. Penamaan busana dengan memanfaatkan nama beruang ini memiliki makna sebagai suatu kehangatan. Kulit beruang yang kasar dan lebat ini dapat melindungi tubuh dari hawa dingin. Maka Penamaan busana dengan memanfaatkan nama hewan beruang ini memiliki makna bahwa pakaian tersebut memberikan rasa nyaman dan hangat bagi si pemakai, terutama dalam menghadapi musim dingin serta memberikan kewibawaan.

Pada nama Swan Flowing Shirt, kata tersebut mempunyai leksem swan, leksem flowing, dan leksem shirt. Leksem swan, jika diartikan dalam bahasa Indonesia yaitu sejenis angsa dan mempunyai kategori nomina atau kata benda. Leksem flowing, jika diartikan dalam bahasa Indonesia yaitu mengalir dan mempunyai kategori verba atau kata kerja. Sedangkan leksem shirt, jika diartikan dalam bahasa Indonesia yaitu kaos dan mempunyai kategori nomina atau kata benda. Angsa merupakan habitat yang hidup di air dan terkenal akan kesetiaannya. Di Cina, hewan ini dijadikan orang tua sebagai hadiah ulang pernikahan anaknya. Penamaan busana dengan nama angsa ini melambangkan kesetiaan bagi si pemakai. Dengan menggunakan pakaian tersebut, 
pemakai dapat dipandang sebagai perempuan yang setia.

Pada nama tunik sarimbit merak, kata tersebut terdapat leksem tunik, sarimbit dan leksem merak. Leksem tunik, dalam bahasa Indonesia yaitu sebuah jubbah yang besar. Leksem sarimbit memiliki padanan makna dengan kata sepasang, sedangkan leksem merak, dalam bahasa Indonesia adalah burung besar dengan kepala kecil. Merak merupakan salah satu burung yang habitatnya mulai punah. Untuk itulah merak menjadi salah satu burung yang dilindungi. Keelokan dan kecantikan bunga merak ketika melambungkan sayapnya, mampu memikat jutaan pasang mata yang memandang. Untuk itu penamaan busana wanita dengan nama merak ini memiliki makna agar si pemakai juga memiliki keindahan layaknya burung merak.

\section{Nomina}

Dalam penelitian ini ditemukan nama busana wanita yang menggunakan nomina. Data tersebut seperti berikut:

Tabel 4 Nomina Pada Merek Pakaian

\begin{tabular}{|c|c|c|}
\hline No & Jenis & Makna \\
\hline 1 & $\begin{array}{ll}\text { Pickle } & \text { Mandarin } \\
\text { Shirt } & \\
\end{array}$ & $\begin{array}{l}\text { Kemeja Acar } \\
\text { Mandarin }\end{array}$ \\
\hline 2 & Swirl Outerwear & $\begin{array}{ll}\text { Pakaian Luar } \\
\text { Pusaran }\end{array}$ \\
\hline 3 & $\begin{array}{l}\text { Turquoise Buttoned } \\
\text { Shirt }\end{array}$ & $\begin{array}{l}\text { Kemeja } \\
\text { Kancing Pirus }\end{array}$ \\
\hline 4 & Layered Outerwear & $\begin{array}{ll}\text { Pakaian } & \text { Luar } \\
\text { Berlapis } & \\
\end{array}$ \\
\hline 5 & $\begin{array}{ll}\text { Cherry } & \text { Stripes } \\
\text { Basic } & \\
\end{array}$ & $\begin{array}{l}\text { Garis-Garis } \\
\text { Ceri Dasar } \\
\end{array}$ \\
\hline 6 & Foggy Stripes Basic & $\begin{array}{l}\text { Garis-Garis } \\
\text { Bekabut Dasar }\end{array}$ \\
\hline 7 & $\begin{array}{ll}\text { Gingham } & \text { Daily } \\
\text { Shirt } & \end{array}$ & $\begin{array}{l}\text { Kemeja Harian } \\
\text { Motif Kotak }\end{array}$ \\
\hline 8 & $\begin{array}{l}\text { Bohemian Flowing } \\
\text { Shirt }\end{array}$ & $\begin{array}{l}\text { Baju Bohemian } \\
\text { Mengalir }\end{array}$ \\
\hline 9 & Glitter Outerwear & $\begin{array}{l}\text { Pakaian Luar } \\
\text { Gemerlap }\end{array}$ \\
\hline 10 & Stripes Outerwear & $\begin{array}{l}\text { Pakaian Luar } \\
\text { Garis-Garis }\end{array}$ \\
\hline 11 & n Flowing & Kanon \\
\hline
\end{tabular}

\begin{tabular}{ll}
\hline & Mengalir \\
\hline 12 Candy Daily & $\begin{array}{l}\text { Permen Setiap } \\
\text { Hari }\end{array}$ \\
\hline
\end{tabular}

Data di atas menunjukkan nama-nama busana wanita menggunakan nomina sebagai penanda busana tersebut. Nama tersebut sering digunakan dalam nama busana wanita yang setiap nama memiliki model atau gaya baju yang berbeda. Pada setiap nama memiliki model seperti baju atasan dan outer. Nama yang digunakan mempunyai kategori nomina atau nama benda.

Misalnya pada nama Glitter Outerwear, pada kata tersebut mempunyai leksem Glitter, dan leksem Outerwear. Leksem Glitter, jika diartikan dalam bahasa Indonesia berarti gemerlap dan mempunyai kategori nomina. Leksem Outerwear jika diartikan dalam bahasa Indonesia yaitu pakaian luar dan mempunyai kategori nomina atau kata benda. Dengan demikian penamaan pakaian tersebut memiliki makna pakaian luar yang bergemerlap. Penamaan baju dengan nama permata ini memiliki maksud bahwa busana tersebut memiliki pancaran aura yang mampu memikat hati orang lain. Dengan memakai pakaian tersebut, mereka akan tampil lebih elegan seperti memiliki sinar pancaran yang dapat meluluhkan hati setiap orang yang melihatnya.

Pada nama Pickle Mandarin Shirt, kata tersebut terdapat leksem pickle, leksem mandarin, dan leksem shirt. Leksem pickle jika diartikan dalam bahasa Indonesia adalah acar atau asinan dan merupakan kategori nomina atau nama benda. Leksem mandarin merupakan bahasa daerah yang digunakan di Tiongkok, Taiwan, dan Singapura. Sedangkan leksem shirt, jika diartikan dalam bahasa Indonesia adalah kemeja atau hem dan merupakan kategori nomina atau kata benda. Penamaan busana dengan nama demikian bermaksud memberikan makna bahwa si pemakai busana akan tampak seperti layaknya orang Cina. 
Pada nama candy pisket, kata tersebut terdapat leksem candy, dan leksem pisket. Leksem candy jika diartikan dalam bahasa Indonesia adalah permen dan merupakan kategori nomina atau kata benda. Leksem pada kata daily jika diartikan dalam bahasa Indonesia adalah harian dan merupakan kategori nomina atau kata benda. Permen merupakan salah satu dari Kelian makanan yang memiliki rasa manis. Rasa manis yang dimiliki oleh permen tidak hanya disukai oleh anak-anak, tetapi juga semua kalangan dari yang muda hingga tua. Penamaan pakaian dengan nama permen ini memiliki maksud bahwa pakaian tersebut terasa manis digunakan atau dipandang. Dengan menggunakan pakaian tersebut maka penggunanya akan tampil percaya diri dan mampu memikat hati setiap orang.

\section{PENUTUP}

Dari hasil analisis yang telah dilakukan di atas, ditemukan beberapa nama-nama

\section{DAFTAR PUSTAKA}

Bakti, I. S. (2018). Pergeseran Pola

Pemberian Nama Anak Pada Generasi Millenial dan Post-Millenial, 12, 2437.

Fitria, T. N. (2017). Bisnis Jual Beli Online (Online Shop) dalam Hukum Islam Dan Hukum Negara. JURNAL ILMIAH EKONOMI ISLAM, 3(1), 5262.

Hapsari, A. D., \& Mohammad, I. (2018).

Analisis Segmentasi Pasar Fashion Wanita Berdasarkan Motif Pembelian Dan Shopping Lifestyle ( Survei Pada Konsumen Fashion Item Wanita Di Kota Surabaya Dan Malang ). Jurnal Administrasi Bisnis (JAB)|Vol., 64(2), 27-35.

Inderasari, E. (2019). Satuan Ekspresi

Penamaan dan Persamaan Warna dalam Produk Lipstik, 67-76.

Lutfiati, D. (2017). Minat Konsumen Terhadap Batik Mirota Surabaya., Vol busana wanita yang telah digunakan. Namanama tersebut telah dikategorikan sesuai dengan pengklasifikasian yang kebanyakan mempunyai kategori nama atau kata benda. Analisis yang dilakukan telah menemukan data 12 yang mewakili dalam penggunaan nama orang, 9 yang menggunakan nama tumbuhan, 7 nama binatang, dan 12 menggunakan nomina. Semua data tersebut telah dianalisis menggunakan makna leksikal. Tentunya tidak melupakan analisis yang melatar belakangi penamaan busana tersebut. Seperti faktor penemu, kesesuain jenis bahan, singkatan, wilayah, dan kesamaan ciri produk dengan yang di contoh pada gambar. Penamaan busana dengan nama-nama seperti nama orang, hewan, tumbuhan dan nama benda memiliki tujuan untuk memberikan makna pada produk busana yang dibuat sesuai dengan sifat atau karakter dari nama produk tersebut.

1.

Poerwadarminta.W.J. (2005). Kamus Umum Bahasa Indonesia. Jakarta: Balai Pustaka.

Rahmawati, N. (2018). Makna Leksikal dan Gramatikal Pada Judul Berita Surat Kabar Pos Kota (Kajian Semantik), 6(1).

Rifauddin, M. (2016). Fenomena Cyberbullying Pada Remaja (Studi Analisis Media Sosial Facebook). KHIZANAH AL-HIKMAH J, 4(1), 3544.

Rohardiyanto, I. (2019). Komprehensi Psikososiosemantik Nama Diri Mahasiswa IAIN Surakrta, II(2), 169196.

Sugiyono. (2012). Metode Penelitian Kuantitatif, Kualitatif, Dan $R \& D$. Bandung: Alfabeta.

Suwandi, S. (2008). Semantik Pengantar Kajian Makna. Jakarta: Media Perkasa.

Ulfiana, E. (2016). Satuan Ekspresi Pengungkap Aroma Parfum. Yogyakarta: Gajah Mada Press. 
Umboh, Z., Lisbeth, M., \& Reitty, S. (2018). Pengaruh Shopping Lifestyle , Fashion Involvement Dan Sales Promotion Terhadap Impulse Buying Behaviour Konsumen Wanita Di.
Jurnal EMBA, 6(3), 1638 - 1647.

Wijana, I. D. P. (2015). Pengantar

Semantik Bahasa Indonesia.

Yogyakarta: Pustaka Pelajar. 